\title{
Most Coarctations, Recoarctations, and Coarctation-Related Aneurysms Should Be Treated Endovascularly
}

\author{
Edgar Luis Galiñanes, MD' ${ }^{1}$ Zvonimir Krajcer, MD* \\ ${ }^{1}$ Department of Cardiovascular Surgery, Texas Heart Institute, Division of Vascular Surgery and Endovascular Therapy, Michael E. \\ DeBakey Department of Surgery, Houston, Texas, USA \\ ${ }^{2}$ Department of Cardiology, Texas Heart Institute, Section of Cardiology, Department of Medicine, Baylor College of Medicine, \\ Houston, Texas, USA
}

Based on a Presentation at the 2013 VEITH Symposium, November 19-23, 2013 (New York, NY, USA)

\begin{abstract}
For patients with coarctation of the aorta (CoA), surgical intervention results in an overall survival rate nearly twice that of medical management. Therefore, surgical correction of CoA has traditionally been warranted in the majority of patients, even though open repair entails its own complications. With the advent of endovascular technology, many interventionalists hoped that this approach would decrease the complications associated with open surgical repair of CoA. Nevertheless, there is still an ongoing debate about the merits of traditional open surgery versus endovascular therapy. In this review, we discuss the role of these two approaches for the management of $\mathrm{CoA}$, recoarctation, and coarctation-related aneurysms.
\end{abstract}

Copyright $\odot 2015$ Science International Corp.

\section{Key Words}

Coarctation of aorta - Aorta - Endovascular repair • Open repair

\section{Introduction}

Coarctation of the aorta (CoA) has a wide spectrum of manifestations. The disease may be diagnosed at an early age in patients with acyanotic heart disease or may be diagnosed incidentally in adults. Because of this variability in presentation, each clinical scenario involving $\mathrm{CoA}$ is unique, and definitive management should be tailored individually for each patient. We propose that most CoAs, recoarctations, and CoA-related aneurysms are best treated with endovascular techniques and that surgery should be reserved for selected cases.

\section{Open Repair versus Endovascular Surgery}

Traditional open repair of CoA relies on variable techniques, including direct end-to-end repair, aortoplasty, patch repair, and interposition-graft repair. All of these operations entail the cardiovascular and respiratory risks posed by general anesthesia in addition to procedural and periprocedural complications. Many procedural complications are associated with the need for cardiopulmonary bypass and aortic cross-clamping. In addition, open repair often necessitates a median sternotomy or lateral thoracotomy incision, which can result in significant morbidity. Postoperatively, patients often have a prolonged recovery, with average hospital stays lasting longer (c) 2015 AORTA

Published by Science International Corp. ISSN 2325-4637

Fax +12037853552

E-Mail: aorta@scienceinternational.org

http://aorta.scienceinternational.org
Accessible online at:

http://aorta.scienceinternational.org
* Corresponding Author:

Zvonimir Krajcer, MD

Department of Cardiology

Texas Heart Institute

Baylor College of Medicine, Houston, Texas 77030, USA

Tel: +1 713790 9401, Fax: +1 713790 0353, E-Mail: zkrajcer@yahoo.com 
than 1 week, and need physical rehabilitation. The increased morbidity and prolonged recovery usually result in greater hospital expenses.

After performing resection with extended end-to-end anastomosis for CoA in 201 patients from 1991 through 2007, Kaushal and colleagues [1], of the Children's Memorial Hospital, in Chicago, reported an early mortality rate of $2 \%$, in addition to the following morbidity rates: septicemia, 4\%; recurrent laryngeal nerve paresis, $3 \%$; chylothorax, 3\%; pulmonary hypertensive crisis, $1 \%$; and reoperation for ventral-septal-defect closure, mediastinitis, or delayed sternal closure, $2 \%$. Brown and associates [2], of the Mayo Clinic, reported an overall $2.4 \%$ mortality rate for 819 patients with isolated CoA who underwent primary operative repair between 1946 and 2005 by means of extended end-to-end anastomosis, patch angioplasty, interposition grafting, bypass grafting, or subclavian flap or "other" repair. Moreover, Preventza and coauthors [3], of the Texas Heart Institute, reported a $1.9 \% 30$-day mortality rate with re-operative surgery in 53 patients with CoA-related aneurysms. In addition, these surgeons reported the following complications: vocal-cord paralysis, $20.8 \%$; need for prolonged mechanical ventilation, $11.3 \%$; reoperation for bleeding, 7.5\%; neurologic events, 5.7\%; acute renal failure, $5.7 \%$; and need for a tracheostomy, 3.8\%.

In the Quebec Native Coarctation of the Aorta Study [4], investigators retrospectively compared surgical repair to transcatheter intervention (angioplasty) in 80 patients (mean age, 12 years) treated between 1998 and 2004. Procedure-related complications were far more common in the surgical group $(50 \%)$ than in the angioplasty group (18\%) $(p=0.005)$. The median hospital stay was 7 days for the surgical group and 1 day for the angioplasty group $(p<0.001)$. At $38 \pm 21$ months, however, the rate of follow-up repeat intervention was higher in the angioplasty group $(32 \%)$ than in the surgical group $(0 \%)(p<0.0001)$.

Proponents of open surgical repair often argue that in endovascular procedures, the short-term benefits of decreased morbidity and mortality are gained at the expense of durability and longevity, but that is not the case. Jenkins and colleagues [5] reported that most patients who undergo open repair are symptom-free for approximately 20 years after their initial operation, but $30 \%$ to $75 \%$ of these patients later have recurrent hypertension.
The direct end-to-end sutured anastomosis originally described by Crafoord and Nylin [6] in 1945 has largely been abandoned due to high rates of recoarctation, and many surgeons now perform alternative variations [7]. Kaushal and associates [1] reported a $4 \%$ reintervention rate after extended end-to-end anastomosis; three of their patients needed balloon angioplasty, and five patients required reoperation. In their study, $75 \%$ of reinterventions occurred within the first year after initial surgery. Alternatives, such as patch aortoplasty, have long been associated with high rates of aneurysmal formation (20-40\%) [8]. The addition of polytetrafluoroethylene (PTFE) for aortoplasty lowered rates of aneurysmal disease but, unfortunately, increased rates of recoarctation to 25\% [9].

In 2013, after analyzing surgical repairs of isolated CoAs performed in 819 patients at the Mayo Clinic over the past 60 years, Brown and colleagues [2] concluded that lifelong surveillance is mandatory after surgical repair. They reported that in comparison to age- and sex-matched populations, patients who underwent open repair had reduced long-term survival. Repair at an early age was an independent risk factor for reintervention. At 30 years' follow-up, patients who underwent an initial repair before 1 year of age had an average reintervention rate of $31.1 \%$, and patients who underwent an initial repair before 5 years of age had an average reintervention rate of $73.3 \%$.

Endovascular approaches have the advantage of being performed under local anesthesia with sedation, avoiding the risks of general anesthesia. In addition, these procedures can be performed completely percutaneously, avoiding the morbidities that may accompany median sternotomy or lateral thoracotomy incisions. After endovascular treatment, patients often have shorter hospital stays, avoiding many common postsurgical complications such as urinary tract infections, pneumonia, and deep venous thrombosis.

In 2011, the American College of Cardiology's Congenital Cardiovascular Interventional Study Consortium published a report that compared surgery, stenting, and balloon angioplasty for the treatment of CoA [10]. This multicenter, observational, nonrandomized study involved 350 patients from 36 institutions. Compared with surgery, stent placement appeared to produce hemodynamically equivalent results during follow-up observation. Moreover, 
Table 1. Summary of selected series involving the use of stent grafts to treat native coarctation of the aorta (CoA), recurrent CoA, and CoA-associated aneurysms.

\begin{tabular}{|c|c|c|c|c|c|c|c|c|c|}
\hline Year & First author & $\begin{array}{l}\text { No. of } \\
\text { patients }\end{array}$ & $\begin{array}{l}\text { Mean } \\
\text { age }(y)\end{array}$ & $\begin{array}{l}\text { Stent } \\
\text { type(s) }\end{array}$ & Stent model & $\begin{array}{l}\text { Mean FU } \\
\text { period } \\
(\mathrm{mo})\end{array}$ & $\begin{array}{l}\text { Morbidity } \\
\text { rate (\%) }\end{array}$ & $\begin{array}{l}\text { Mortality } \\
\text { rate }(\%)\end{array}$ & $\begin{array}{l}\text { Reintervention } \\
\text { rate }(\%)\end{array}$ \\
\hline 2006 & Tzifa [19] & 30 & 28 & CS & Cheatham-Platinum & 11 & 13 & 0 & 13 \\
\hline 2007 & Butera [13] & 33 & 18 & CS & Cheatham-Platinum & 12 & 0 & 0 & 3 \\
\hline 2008 & Tanous [18] & 22 & 39 & CS & Cheatham-Platinum & 12 & 4 & 0 & 13 \\
\hline 2009 & Botta [1 1] & 11 & 45 & CS & $\begin{array}{l}\text { Talent/Naliant } \\
\text { Medtronic }\end{array}$ & 44 & 14.3 & 0 & 0 \\
\hline 2010 & Shennib [17] & 22 & 40 & BES, CS & $\begin{array}{l}\text { Palmaz, Gore-TAG, } \\
\text { Cook Zenith }\end{array}$ & 31 & 0 & 0 & 4 \\
\hline 2010 & Bruckheimer [12] & 25 & - & CS & Advanta V12D & 4.9 & 0 & 0 & 0 \\
\hline 2012 & Roselli [16] & 59 & 38 & CS, BES & $\begin{array}{l}\text { Gore-TAG, Cook } \\
\text { Zenith }\end{array}$ & 56 & 3 & 0 & 12 \\
\hline 2013 & Preventza [3] & 11 & 39 & CS & $\begin{array}{l}\text { Gore-TAG, Talent/ } \\
\text { Captivia, Medtronic }\end{array}$ & 40 & 0 & 0 & 0 \\
\hline 2013 & Khavandi [14] & 17 & 39 & CS & $\begin{array}{l}\text { Valiant Medtronic, } \\
\text { Cook Zenith }\end{array}$ & 31 & 23 & 0 & 0 \\
\hline 2014 & Perera [15] & 13 & 45 & CS & $\begin{array}{l}\text { Gore-TAG, Valiant } \\
\text { Medtronic }\end{array}$ & 15 & 0 & 0 & 7 \\
\hline
\end{tabular}

BES = balloon expandable stent; $\mathrm{CS}=$ covered stent; $\mathrm{FU}=$ follow-up

stenting was associated with significantly fewer complications [2.3\% versus $8.1 \%$ for surgery and $9.8 \%$ for balloon angioplasty $(p<0.001)]$ and shorter hospital stays [2.4 days versus 6.4 days for surgery $(p<0.001)$ ]. The reintervention rate was higher in the stent group; however, this finding was attributed to staged procedures or patient somatic growth, and all reinterventions carried a similar low risk of morbidity and mortality.

Recently, use of covered stents has been advocated for $\mathrm{CoA}$, recoarctation, and CoA-related aneurysms (Table 1) [3, 11-19]. In 2009, Botta and associates [11] reported their experience using thoracic stent grafts in the treatment of CoA. They reported a 100\% technical success rate, a $0 \%$ mortality rate, and a $0 \%$ reintervention rate after a mean follow-up period of 44 months. The incidence of procedural complications was $14 \%$. Five years later, Perera and coworkers [15] reported similar rates of technical success, mortality, and reinterventions; in addition, their procedural complication rate was $0 \%$, most likely because of increased experience and advances in technology with newer lower-profile systems. Theoretically, covered stents have the advantages of reducing the extent of the intimal tear, creating a framework for neointimal growth, and allowing control of the integrity of the aortic wall. For these reasons, they should be the standard of care for managing coexistent aneurysmal disease.

\section{Conclusion}

In patients with $\mathrm{CoA}$, recoarctation, or a CoA-related aneurysm, open surgical repair is associated with an unnecessary risk of morbidity and mortality. In patients more than 1 year old, endovascular procedures have been shown to yield immediate outcomes similar to those of surgery, defined as hemodynamically controlled hypertension in the follow-up period [4]. Any argument regarding endovascular reintervention, however negligible, is formidable, because such reintervention is associated with the same risks of morbidity and mortality as the initial operation [11]. Furthermore, belief in the longevity of surgical repair 
for $\mathrm{CoA}$ is erroneous, as a large percentage of these repairs are plagued with recoarctation and CoA-related aneurysms [5]. Unfortunately, reoperative surgery in these patients entails increased risks of morbidity and mortality [3].

With the application of endovascular surgery to CoA, interventionalists have gained a new armamentarium for addressing this condition. Both interventions and reinterventions are associated with low risks of morbidity and mortality. As technology continues to evolve, the role of endovascular surgery will be further defined, clearly demonstrating that this approach is optimal for managing the majority of $\mathrm{CoA}$ and finally silencing this debate.

\section{Conflict of Interest}

The authors have no conflicts of interest relevant to this publication.

\section{Comment on this Article or Ask a Question}

\section{References}

1. Kaushal $\mathrm{S}$, Backer $\mathrm{CL}$, Patel JN, Patel SK, Walker BL, Weigel TJ, et al. Coarctation of the aorta: Midterm outcomes of resection with extended end-to-end anastomosis. Ann Thorac Surg. 2009;88:1932-1938. DOI: 10.1016/j.athoracsur.2009.08.035

2. Brown ML, Burkhart HM, Connolly HM, Dearani JA, Cetta F, Li Z, et al. Coarctation of the aorta: Lifelong surveillance is mandatory following surgical repair. J Am Coll Cardiol. 2013;62:1020-1025. DOI: 10.1016/j.jacc.2013.06.016

3. Preventza O, Livesay JJ, Cooley DA, Krajcer Z, Cheong BY, Coselli JS. Coarctationassociated aneurysms: A localized disease or diffuse aortopathy. Ann Thorac Surg. 2013;95:1961-1967. DOI: 10.1016/j.athoracsur.2013.03.062

4. Rodes-Cabau J, Miro J, Dancea A, Ibrahim $\mathrm{R}$, Piette $\mathrm{E}$, Lapierre $\mathrm{C}$, et al. Comparison of surgical and transcatheter treatment for native coarctation of the aorta in patients > or $=1$ year old. The Quebec Native Coarctation of the Aorta study. Am Heart J. 2007;154:186-192. DOI: 10.1016/j. ahj.2007.03.046

5. Jenkins NP, Ward C. Coarctation of the aorta: Natural history and outcome after surgical treatment. QJM. 1999;92:365-371. DOI: 10.1093/qjmed/92.7.365

6. Crafoord C, Nylin G. Congenital coarctation of the aorta and its surgical treatment. J Thorac Cardiovasc Surg. 1945;14:347-361. DOI: 10.1016/0002-8703(46)90334-1

7. Kappetein AP, Zwinderman $A H$, Bogers AJ, Rohmer J, Huysmans HA. More than thirty-five years of coarctation repair. An unexpected high relapse rate. JThorac Cardiovasc Surg. 1994;107:87-95. PMID: 8283924

8. Bromberg BI, Beekman RH, Rocchini AP, Snider AR, Bank ER, Heidelberger K, et al. Aortic aneurysm after patch aortoplasty repair of coarctation: A prospective analysis of prevalence, screening tests and risks. J Am Coll Cardiol. 1989;14: 734-741. DOI: 10.1016/0735-1097(89)90119-8

9. Walhout RJ, Lekkerkerker $\mathrm{JC}$, Oron $\mathrm{GH}$, Hitchcock FJ, Meijboom EJ, Bennink GB. Comparison of polytetrafluoroethylene patch aortoplasty and end-to-end anastomosis for coarctation of the aorta. J Thorac Cardiovasc Surg. 2003;126:521-528. DOI: 10.1016/S0022-5223(03)00030-8

10. Forbes TJ, Kim DW, Du W, Turner DR, Holzer R, Amin Z, et al. Comparison of surgical, stent, and balloon angioplasty treatment of native coarctation of the aorta: An observational study by the CCISC (Congenital Cardiovascular Interventional Study Consortium). J Am Coll Cardiol. 2011;58:2664-2674. DOI: 10.1016/j. jacc.2011.08.053

11. Botta L, Russo V, Oppido G, Rosati M, Massi $F$, Lovato $L$, et al. Role of endovascular repair in the management of late pseudo-aneurysms following open surgery for aortic coarctation. Eur J Cardiothorac Surg. 2009;36:670-674. DOI: 10.1016/j. ejcts.2009.04.056

12. Bruckheimer $E$, Birk $E$, Santiago R, Dagan T, Esteves C, Pedra CA. Coarctation of the aorta treated with the Advanta V12 large diameter stent: Acute results. Catheter Cardiovasc Interv. 2010;75:402-406. DOI: 10.1002/ccd.22280

13. Butera G, Piazza L, Chessa M, Negura DG, Rosti L, Abella R, et al. Covered stents in patients with complex aortic coarctations. Am Heart J. 2007;154:795-800. DOI: 10.1016/j.ahj.2007.06.018

14. Khavandi A, Bentham J, Marlais M, Martin RP, Morgan GJ, Parry AJ, et al. Transcatheter and endovascular stent graft management of coarctation-related pseudoaneurysms. Heart. 2013;99:1275-1281. DOI: 10.1136/ heartjnl-2012-303488
15. Perera $A H$, Rudarakanchana $N$, Hamady M, Kashef E, Mireskandari M, Uebing A, et al. New-generation stent grafts for endovascular management of thoracic pseudoaneurysms after aortic coarctation repair. J Vasc Surg. 2014;60:330-336. DOI: 10.1016/j.jvs.2014.02.050

16. Roselli EE, Qureshi A, Idrees J, Lima B, Greenberg RK, Svensson LG, et al. Open, hybrid, and endovascular treatment for aortic coarctation and postrepair aneurysm in adolescents and adults. Ann Thorac Surg. 2012;94:751-756. DOI: 10.1016/j.athoracsur. 2012.04.033

17. Shennib H, Rodriguez-Lopez J, Ramaiah V, Wheatley G, Kpodonu J, Williams J, et al. Endovascular management of adult coarctation and its complications: Intermediate results in a cohort of 22 patients. Eur J Cardiothorac Surg. 2010;37:322-327. PMID: 19635674

18. Tanous D, Collins N, Dehghani P, Benson LN, Horlick EM. Covered stents in the management of coarctation of the aorta in the adult: Initial results and 1-year angiographic and hemodynamic follow-up. Int J Cardiol. 2010;140:287-295. DOI: 10.1016/j. ijcard.2008.11.085

19. Tzifa A, EwertP, Brzezinska-Rajszys G, Peters B, Zubrzycka M, Rosenthal E, et al. Covered Cheatham-platinum stents for aortic coarctation: Early and intermediate-term results. J Am Coll Cardiol. 2006;47:1457-1463. DOI: 10.1016/j.jacc.2005.11.061

Cite this article as: Galiñanes EL, Krajcer Z. Most Coarctations, Recoarctations, and Coarctation-Related Aneurysms Should Be Treated Endovascularly. AORTA (Stamford). 2015;3(4):136-139. DOI: http://dx.doi.org/10.12945/j.aorta. 2015.14.049 